\title{
Biomass Ashes for Acid Mine Drainage Remediation
}

\author{
Anna A. Bogush ${ }^{1,2,3} \cdot$ Cosmina Dabu $^{4} \cdot$ Vera D. Tikhova ${ }^{5} \cdot$ Jong Kyu Kim $^{6} \cdot$ Luiza C. Campos $^{7}$ (])
}

Received: 20 December 2018 / Accepted: 4 September 2019 / Published online: 13 September 2019

(c) The Author(s) 2019

\begin{abstract}
Acid mine drainage (AMD) is the largest environmental problem facing the world mining and processing industry because it has low $\mathrm{pH}$ and can contain high concentrations of potential pollutants. Biomass ash (BA) can be considered as a potential material for AMD treatment. The main goal of this work was to investigate potential use of Biomass ash of CPK-LA and PK-LA types for AMD remediation. Four UK BAs from different fuels (i.e. straw, meat and bone meal, poultry litter), synthetic AMD, and raw AMDs (Belovo and Ursk) were used for the AMD treatment experiments. Batch experiments showed that in $1 \mathrm{~h}$ the biomass ash from straw combustion can effectively neutralise the synthetic AMD and the Belovo AMD with removal of potential pollutants at the liquid-to-solid ratio (L/S) of 100-250 and 10-50, respectively. The biomass ashes from straw and poultry litter combustion can effectively remove pollutants from the Ursk AMD at L/S 100 and adjust pH. The metal concentrations of those treated AMDs met receiving water quality standards. Potential pollutants precipitated as carbonate/hydroxide/sulphate, co-precipitated with Fe oxyhydroxides and Ca phosphates, and appeared as new phases such as $\mathrm{Ca}, \mathrm{Cu}, \mathrm{Zn}$ phosphates and $\mathrm{Ca}, \mathrm{Fe}$ phosphates. This investigation is essential for development of appropriate, environmentally friendly and economically rational waste management.
\end{abstract}

\section{Graphic Abstract}
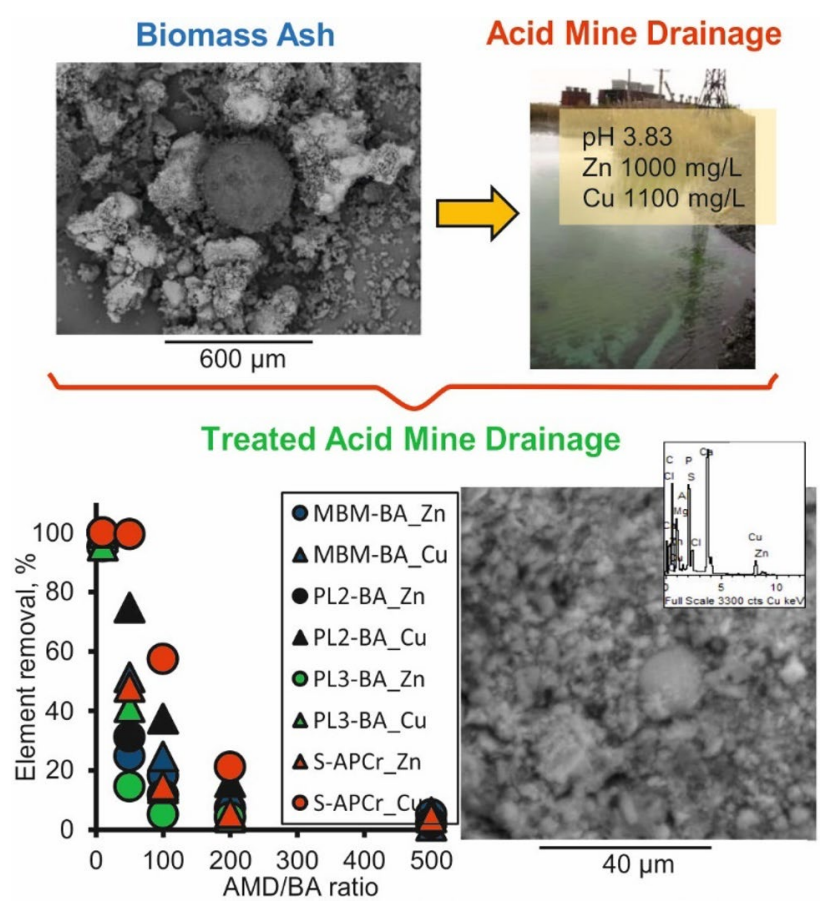

Keywords Biomass ash $\cdot$ AMD remediation $\cdot$ Industrial water treatment $\cdot$ Straw $\cdot$ Meat and bone meal $\cdot$ Poultry litter

Extended author information available on the last page of the article 


\section{Statement of Novelty}

This paper presents novel research on using biomass ashes of CPK-LA and PK-LA types (e.g., straw and animal residue) for acid mine drainage treatment. This study highlights industrial symbiosis that is becoming very important in sustainable development.

\section{Introduction}

Acid mine drainage (AMD) is the largest environmental problem facing the world mining and processing industry [1-9]. AMD is formed when material containing sulfides (generally pyrite- $-\mathrm{FeS}_{2}$ ) is exposed to oxygen and water. The decomposition of pyrite is accelerated by natural bacteria that oxidize it, yielding ferrous iron and sulfate [1]. The resulting water that comes in contact with these oxidized products is characterised by a low $\mathrm{pH}$ and high concentrations of potential pollutants (e.g. $\mathrm{Pb}, \mathrm{Cd}, \mathrm{Hg}$, $\mathrm{As}, \mathrm{Sb}$, etc.), which can be several orders of magnitude higher than the maximum permissible limits (MPLs) for the quality standards of the receiving water $[5,7,8,10]$.

Active and passive systems using physicochemical, chemical or biological treatment are presently employed for AMD remediation [11-15]. Various materials such as limestone, lime, clay, activated carbon, zeolite, iron (III) hydroxide, cellulose, rice husks, coal fly ash, waste green seeds and peat-humic agent are used for AMD remediation [9, 16-24]. Generally, inexpensive alkaline materials like limestone and lime are used for AMD treatment that leads to $\mathrm{pH}$ adjustment and metal precipitation mainly as hydroxides and carbonates. However, it needs high dosage of that materials to meet particular water quality standards because limestone is usually coated by ferric hydroxide and becomes ineffective; and hydrated lime powder is hydrophobic and extensive mechanical mixing is required (Table 1 in Supplementary Data from [9]). Also, large amount of bulky sludge is produced, that needs vast area for sludge storage and long-term stability of sludge neutralization is poorly understood. Therefore, alternative inexpensive and effective materials are in a high demand for AMD treatment [25].

Synergistic solutions, such as industrial symbiosis, when waste/by-product from one industry can be considered as resources for another industry, are becoming very attractive for sustainable development and circular economy. Biomass ash (BA), which is a by-product of burning biomass in conventional power station, can be considered as a potential material for AMD treatment. BAs are complex alkaline inorganic-organic mixtures with polycomponent, heterogeneous and variable composition [26-28]. Biomass combustion is an important part of the global renewable energy which is growing fast worldwide [29]. Moreover, Vassilev et al. [27, 30] estimated that amount of biomass ashes generated worldwide annually (480 Mtpa) is comparable to coal ash production (780 Mtpa) and expect to be growing fast in the near future. Both coal and biomass ashes are alkaline ( $\mathrm{pH} 9-12)$ materials. However, they are quite different in composition, for example, coal fly ashes are generally a siliceous ash consisting of oxides of $\mathrm{Si}, \mathrm{Al}$ and $\mathrm{Fe}$ and contain less $\mathrm{CaO}[27,31]$ and belong to $\mathrm{S}$ or/and $\mathrm{SC}$ type with high or/and medium acid tendency (Fig. 1), while biomass ashes are very variable in composition (Fig. 1) and can represent the whole spectrum of ash types according to Vassilev's chemical classification [27]. Also, coal fly ashes quite often contain high concentrations of potential pollutants such as heavy metals $[32,33]$, comparing to biomass ashes, and may also have additional negative environmental impacts when using as neutralizing material for AMD treatment. The use of coal fly ashes from coal power plants for AMD treatment has been widely investigated [34-41]. However, there are few studies about AMD remediation by biomass ashes, particularly, from wooden chip and rice husk combustion [42-44]. Based on Vassilev's chemical classification for biomass ashes [27], wooden chip fly ash generally belongs to the $\mathrm{C}$ or/and SC types with low or/and medium acid tendency, and rice husk fly ash mainly represents the $\mathrm{S}$ type with high acid tendency. For instance, the biomass ash from wooden chip combustion, with dominant components of $\mathrm{SiO}_{2}(45.4 \mathrm{wt} \%), \mathrm{CaO}$ (17.8 wt \%), $\mathrm{Al}_{2} \mathrm{O}_{3}$ (13.4 wt \%), and $\mathrm{Fe}_{2} \mathrm{O}_{3}(4.12 \mathrm{wt} \%$ ), that belongs to the $\mathrm{SC}$ type with medium acid tendency (SC-MA type) according to Vassilev's chemical classification for biomass ashes [27], was used for treatment of AMD (pH 2.7; main metal pollutants: $\mathrm{Fe}-20 \mathrm{mg} / \mathrm{L}$; $\mathrm{Al}-15 \mathrm{mg} / \mathrm{L} ; \mathrm{Mn}-5.2 \mathrm{mg} / \mathrm{L}$ ) from open cast brown coal mining in the Czech Republic [42]. Heviankova et al. [42] showed that biomass ash from wooden chip combustion at the liquid-to-solid (L/S) ratio of 345 can effectively adjust $\mathrm{pH}$ of that AMD and remove potential pollutants (e.g., treated AMD: $\mathrm{pH}$ 8.0, the concentrations of $\mathrm{Fe}$ and $\mathrm{Al}$ are below the detection limit, $\mathrm{Mn}=1.4 \mathrm{mg} / \mathrm{L})$. Mohammed et al. [44] used biomass ash (without indication of source of biomass material) enriched in $\mathrm{SiO}_{2}$ and $\mathrm{CaO}$ (e.g., SC-MA type) for treatment of AMD from Bukit Besi (Dungun Terengganu, Malaysia) ( $\mathrm{pH}$ 2.12; main metal pollutants: $\mathrm{Fe}-822 \mathrm{mg} / \mathrm{L} ; \mathrm{Mn}-200 \mathrm{mg} / \mathrm{L} ; \mathrm{Cu}-11 \mathrm{mg} / \mathrm{L}$; $\mathrm{Zn}-8.3 \mathrm{mg} / \mathrm{L} ; \mathrm{Pb}-1.9 \mathrm{mg} / \mathrm{L})$. They showed that, at the $20 \mathrm{~L} / \mathrm{S}$ ratio for 50 days treatment, $\mathrm{pH}$ of treated AMD increased up to 6.8 while the concentration of metals significantly declined with metal removal efficiency varying from 94.8 to $99.79 \%$. Nasir et al. [43] compared coal fly 
ash (SC-MA type) and rice husk ash (S-HA type) for AMD (Udongan Treatment Pond coal mining area in Tanjung Enim, South Sumatra Indonesia; pH 3.93; main metal pollutants: $\mathrm{Fe}-0.81 \mathrm{mg} / \mathrm{L} ; \mathrm{Mn}-10 \mathrm{mg} / \mathrm{L} ; \mathrm{Al}-1.6 \mathrm{mg} / \mathrm{L}$ ) treatment. They showed that coal fly ash, that has similar characteristic with limestone, is more effective for AMD neutralisation and metal removal comparing to $\mathrm{Si}$-reach $\left(\mathrm{SiO}_{2}=90 \%\right)$ rice husk ash that is not very effective.

Vassilev's chemical classification for biomass ashes [27] with the additions from [28] (Fig. 1) can help to make appropriate selection of untested ashes for effective AMD treatment and predict their performance based on knowledge of ash compositions. Therefore, the main criteria for biomass ash selection for effective AMD treatment might be a level of acid tendency (priority should be given to low and/or medium acid tendency) that can contribute to AMD neutralisation and type of ashes with priority to $\mathrm{C}$ type (rich in $\mathrm{CaO}$ ) and/or intermedium types such as CS, CPK, and PK types (Fig. 1) containing phases that can contribute to metal removal (e.g., Ca-bearing and P-bearing phases). For example, biomass ashes of CPK [Fig. 1; bottom ashes (BA) from meat and bone meal (MBM) and poultry litter (PL)] and PK type [air pollution control residues (APCr) from MBM, PL, and straw (S)] with low acid tendency, that was additionally distinguished in [28], might be a better option for

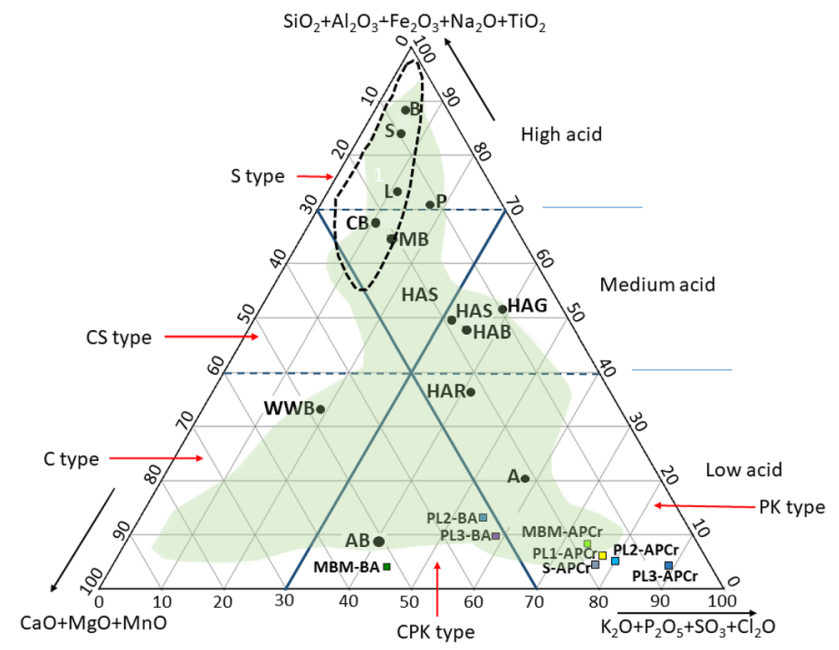

Fig. 1 Chemical classification system of biomass ashes based on $[26,27]$, with position areas of solid fossil fuel ashes (dashed area), biomass ashes (light green area) positions of the eight UK biomass ashes from [28]. $B$ bituminous coal, $S$ sub-bituminous coal, $L$ lignite, $P$ peat, $W W B$ wood and woody biomass, $H A B$ herbaceous and agricultural biomass, $H A G$ herbaceous and agricultural grass, $H A S$ herbaceous and agricultural straw, $H A R$ herbaceous and agricultural residue, $A B$ animal biomass, $M B$ mixture of biomass, $C B$ contaminated biomass, $M B M-B A$ bottom ash from meat and bone meal, $M B M-A P C r$ air pollution control residue from meat and bone meal, $S-A P C r$ air pollution control residue from straw, $P L-B A$ bottom ash from poultry litter, $P L-A P C r$ air pollution control residue from poultry litter
AMD treatment, comparing to ashes from coal, wooden chip and rice husk combustion (Fig. 1). The aim of the present study was to investigate, at laboratory scale, the effectiveness of biomass ashes from straw (PK-LA type), meat and bone meal, and poultry litter combustion (CPK-LA type) to remove heavy metals from synthetic and raw AMDs. This investigation is essential for development of appropriate, environmentally friendly and economically rational waste management.

\section{Materials and Methods}

\section{Biomass Ashes}

According to detailed characterisation of UK biomass power plant residues [28], four UK biomass ashes of CPK type and PK type with low acid (LA) tendency were selected for the AMD treatment experiments (Fig. 1): (1) PK-LA type-straw (S-APCr); (2) CPK-LA type-meat and bone meal (MBM, one sample-MBM-BA); (3) CPK-LA—poultry litter, i.e. a mixture of wood shavings, straw and poultry droppings (PL, two samples-PL2-BA and PL3-BA). Those samples represent three types of biomass ashes [i.e., herbaceous and agricultural biomass (HAB), animal and human biomass wastes $(\mathrm{AB})$, mixed biomass $(\mathrm{MB})]$ based on the classification from Vassilev et al. [27]. Those biomass ashes were selected because they are highly alkaline and contain high concentrations of $\mathrm{Ca}(13-37 \%)$ and $\mathrm{P}(2.2-10 \%)$ [28]. The bulk crystalline phases in the bottom biomass ashes (MBM-BA, PL2-BA, and PL3-BA) included apatite, portlandite, calcite, and quartz [28]. Also, other crystalline phases such as lime, periclase, potassium hydrogen phosphate, arcanite, disodium tricalcium silicate, and albite were identified in those samples [28]. The bulk of the crystalline phases present in the air pollution control residue from the straw combustion (S-APCr) include portlandite, calcium sulphate hydrate, arcanite, sylvite, and apatite [28].

The S-APCr mainly contains fine phases $(<1 \mu \mathrm{m})$ and unburnt straw residues $(200-300 \mu \mathrm{m})$ with a few glassy particles [28] (Fig. 1). Unburnt straw residue consists of C, K, $\mathrm{Ca}, \mathrm{Cl}, \mathrm{P}$ and $\mathrm{Si}$ as major elements, with impurities of $\mathrm{Na}$, $\mathrm{Mg}, \mathrm{Al}, \mathrm{Cu}$ and $\mathrm{S}$ (Fig. 2, point and spectrum 1). The fine phased mainly consists of $\mathrm{Ca}, \mathrm{P}, \mathrm{K}$, and $\mathrm{Cl}$ (Fig. 2, point and spectrum 2). The bottom biomass ashes (MBM-BA, PL2BA, PL3-BA) mainly contain irregular-shaped particle (up to $1 \mathrm{~mm}$ ), aggregates, spherical particles and fine materials (Figs. 3, 4, and 5). The phosphate phases (e.g., apatite, Ca, $\mathrm{K}$ phosphates, etc.) are present in different morphological forms as aggregates, fine phases, unshaped and spherical particles (Figs. 3, 4, and 5).

The $\mathrm{pH}$ of the water leachates at the $\mathrm{L} / \mathrm{S}$ ratio of 10 was high due to the presence of excess $\mathrm{Ca}(\mathrm{OH})_{2}$ in BAs and 

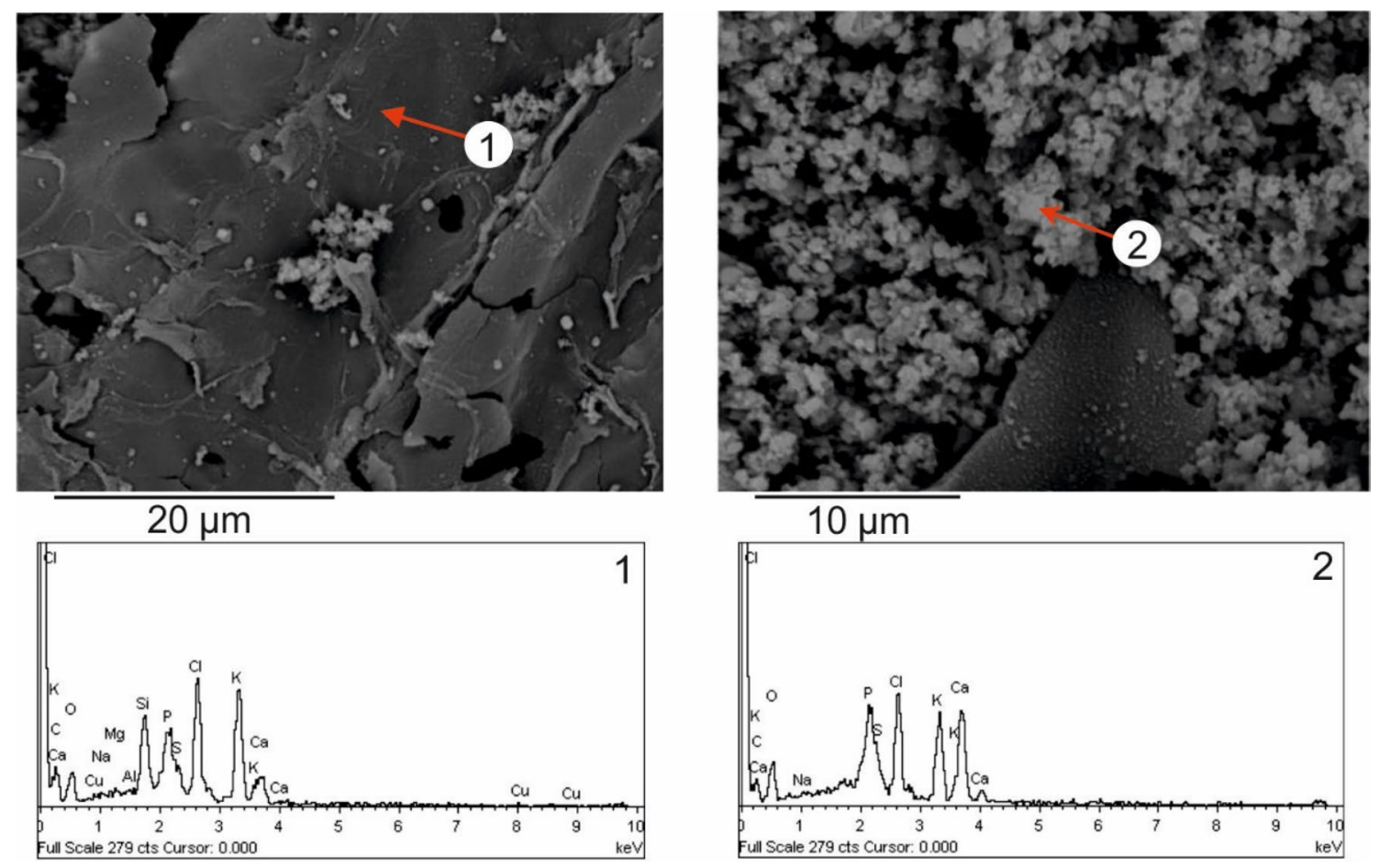

Fig. 2 Scanning electron microscope images of the S-APCr biomass ash with EDS spectra

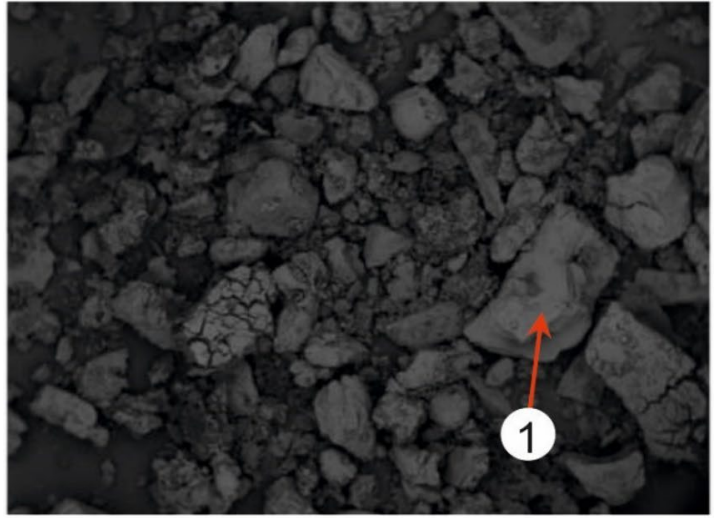

$2 \mathrm{~mm}$

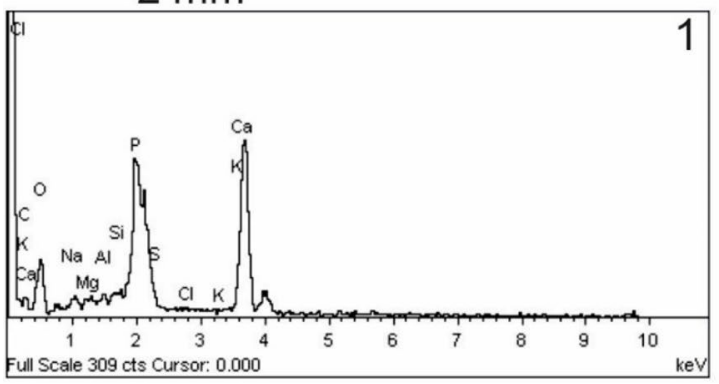

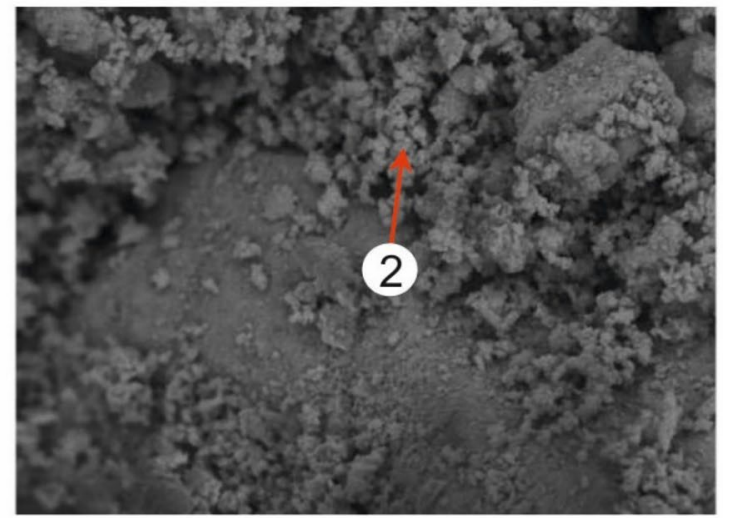

$30 \mu \mathrm{m}$

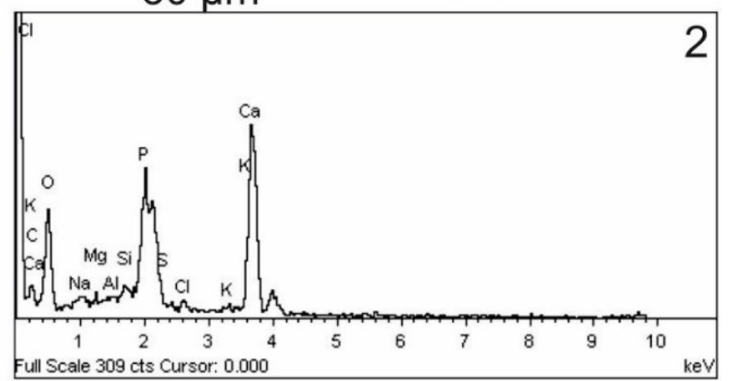

Fig. 3 Scanning electron microscope images of the MBM-BA biomass ash with EDS spectra 

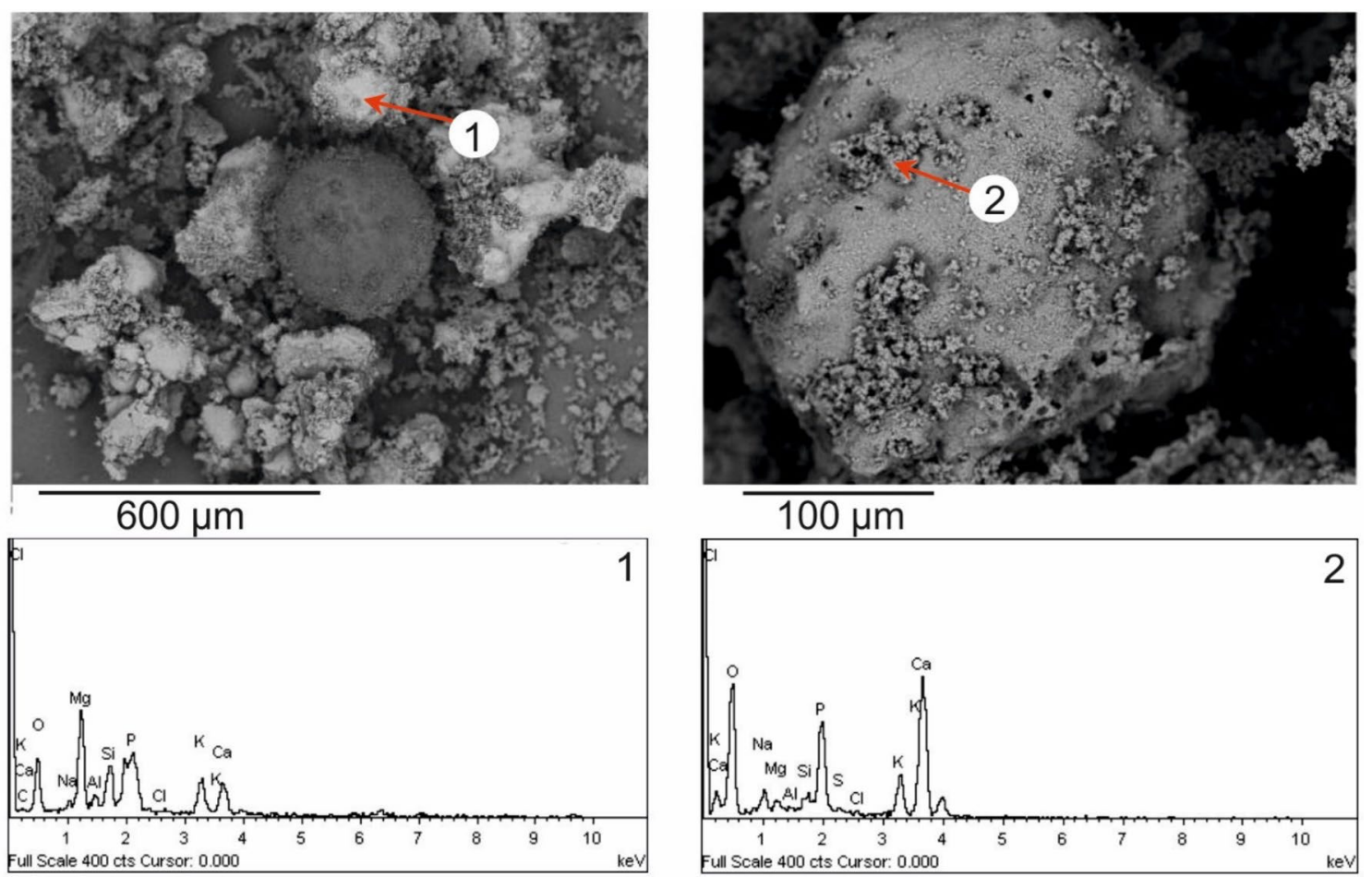

Fig. 4 Scanning electron microscope images of the PL2-BA biomass ash with EDS spectra

varied from 12.22 to 12.78 . It should be noted that a saturated solution of $\mathrm{Ca}(\mathrm{OH})_{2}$ has a $\mathrm{pH}$ of about 12.4 .

Representative subsamples of biomass ashes for batch experiments were obtained by coning and quartering. Then the subsamples were ground using a micronizing mill to produce powder with particle size less than $0.1 \mathrm{~mm}$.

\section{Batch Experiment with Synthetic Acid Mine Drainage (SAMD)}

Romania is a country with a long history of mining [45]. Presently, Romania is still struggling with the effects of AMD and heavy metal pollution of air, soil and waters, which are a serious source of toxicity for plants, animals and people [46-48]. Three old mines are located next to Zlatna in the Almaşu Mare region in the West Apuseni Mountains of Romania. Residents usually collected drinking water from a source several kilometres away because surface and underground waters were contaminated in that area. However, the contaminated waters are still used for livestock and crops irrigation. The National Institute for Research and Development for Industrial Ecology (ECOIND, Romania) has done preliminary tests on three sites (i.e., Haneş mine effluent, Radeş mine effluent and a small river stream located at a nearby village) in order to establish which pollutants were most significant, and the results were used to model a synthetic AMD for the remediation batch experiments (Table 1). The concentrations of Fe, $\mathrm{Zn}$ and $\mathrm{Mn}$ in the AMDs from the Almaşu Mare mining region exceed general standards for discharge of environmental pollutants (GSDEP) [49] (Table 1). At present, all the mines in the area are non-operational but none of them are safely closed down (to prevent AMD leakage) nor is there any method of AMD remediation in place. The AMD leaks from the mines, into creeks, and small rivers that go through villages, and eventually into large river systems.

The SAMD was prepared with $\mathrm{pH}$ and element composition comparable to the AMDs from the Almasu Mare mining region (Table 1). Zinc sulphate heptahydrate $\left(\mathrm{ZnSO}_{4} \cdot 7 \mathrm{H}_{2} \mathrm{O}\right)$, manganese (II) sulphate hydrate $\left(\mathrm{MnSO}_{4} \cdot \mathrm{H}_{2} \mathrm{O}\right)$ and iron (II) sulphate heptahydrate $\left(\mathrm{FeSO}_{4} \cdot 7 \mathrm{H}_{2} \mathrm{O}\right)$ were used to prepare the SAMD. Sulphuric acid was used to adjust the SAMD to $\mathrm{pH}$ 2.7. All used chemicals were from Sigma Aldrich and have analytical grade. The concentrations of $\mathrm{Fe}, \mathrm{Zn}$ and Mn in the SAMD exceed GSDEP in 103, 19, and 27 times, respectively. The SAMD remediation by the biomass ash from straw combustion (S-APCr) was carried out in the batch experiments. The powder of S-APCr biomass ash was added to SAMD with a rotary shaker $($ rate $=30 \mathrm{rpm})$ at the different liquid to solid ratio (i.e., L/S: 100, 250, 350, 500). The $\mathrm{pH}$ of the solution was measured before and after the $\mathrm{S}$-APCr addition. The contact times were $1 \mathrm{~h}$ and $24 \mathrm{~h}$. 

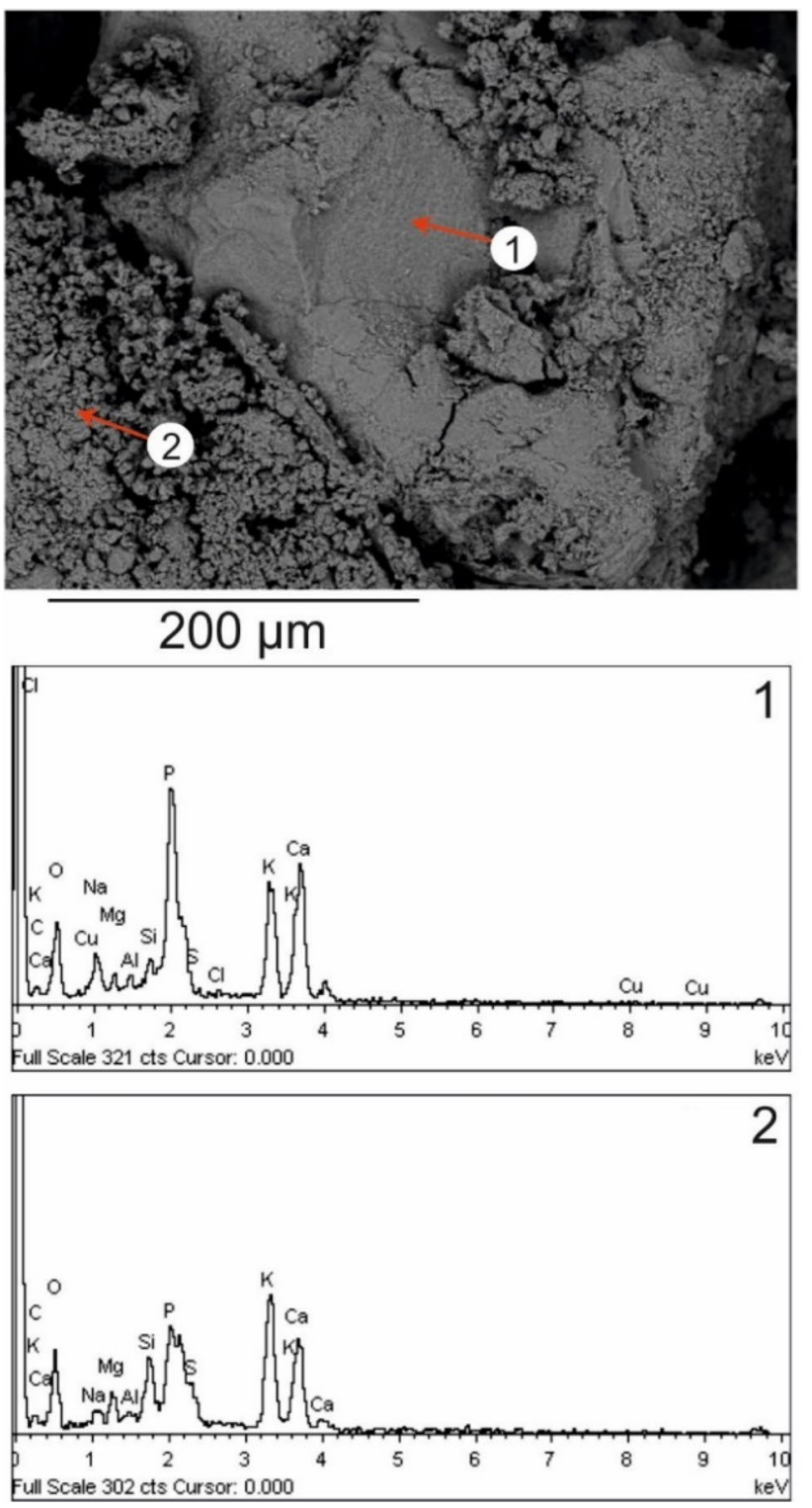

Fig. 5 Scanning electron microscope images of the PL3-BA biomass ash with EDS spectra

Table 1 The element concentrations $(\mathrm{mg} / \mathrm{L})$ and $\mathrm{pH}$ of the raw AMD and SAMD

\begin{tabular}{|c|c|c|c|c|c|}
\hline \multirow{2}{*}{$\begin{array}{l}\text { Param- } \\
\text { eters/ } \\
\text { elements }\end{array}$} & \multicolumn{3}{|l|}{ AMD } & \multirow[b]{2}{*}{ SAMD } & \multirow{2}{*}{$\begin{array}{l}\text { GSDEP } \\
{[49]}\end{array}$} \\
\hline & $\begin{array}{l}\text { Hanes } \\
\text { mine }\end{array}$ & $\begin{array}{l}\text { Rades } \\
\text { mine }\end{array}$ & $\begin{array}{l}\text { Village } \\
\text { river }\end{array}$ & & \\
\hline $\mathrm{pH}$ & 2.72 & 2.69 & 2.79 & 2.7 & $6.0-9.0$ \\
\hline $\mathrm{Zn}$ & 39 & 161 & 45 & 95 & 5.0 \\
\hline $\mathrm{Fe}$ & 152 & 1064 & 72 & 310 & 3.0 \\
\hline $\mathrm{Mn}$ & 271 & 119 & 103 & 54 & 2.0 \\
\hline
\end{tabular}

\section{Batch Experiment with Raw Acid Mine Drainages}

Other series of batch experiments were carried out on the raw AMDs from the Ursk tailings of the Gold concentration plant and from the sludge pond from the Belovo zinc processing plant (Kemerovo region, Russia) that have low $\mathrm{pH}$ and high concentration of heavy metals Table 2 . The concentration of Fe in the Ursk AMD exceeds GSDEP by 90 times. The concentrations of $\mathrm{Zn}, \mathrm{Cu}$, and $\mathrm{Cd}$ in the Belovo AMD exceed GSDEP by 200, 370, and 1.8 times, respectively. The powder of biomass ashes (i.e., S-APCr, MBM-BA, PL2-BA and PL3-BA) were added to AMD (i.e., Ursk AMD and Belovo AMD) with a rotary shaker $($ rate $=30 \mathrm{rpm})$ at different liquid to solid ratios (i.e., L/S: 10, 50, 100, 200, 500). The contact time was $1 \mathrm{~h}$.

\section{Analytical Methods}

The $\mathrm{pH}$ value of the solution was measured before and after the BA addition using a Mettler-Toledo $\mathrm{pH}$ meter. The SAMD-BA and AMD-BA mixtures were filtered through the $0.45 \mu \mathrm{m}$ cellulose nitrate membrane filters (Whatman) and acidified with pure $\mathrm{HNO}_{3}$ (down to $\mathrm{pH}$ 2). The element concentrations (i.e., $\mathrm{Fe}, \mathrm{Al}, \mathrm{Zn}, \mathrm{Cu}, \mathrm{Cd}, \mathrm{Ni}, \mathrm{Cd}$, and $\mathrm{Mn}$ ) were measured by ICP-OES (Varian 730). The experiments were conducted in duplicate or triplicate and the results were averaged. The range of variation did not exceed $7 \%$ for any of the analysed elements.

Then, the removal efficiency was calculated using following equation:

Removal efficiency $(\%)=\left(C_{i}-C_{e}\right) \times 100 / C_{i}$

where $\mathrm{C}_{\mathrm{i}}$ and $\mathrm{C}_{\mathrm{e}}$ are the metal concentrations in the initial and equilibrium solutions $(\mathrm{mg} / \mathrm{L})$ respectively.

$\mathrm{X}$-ray diffraction analysis (XRD; Bruker D8 Discover powder diffractometer using filtered $\mathrm{CuK} \alpha$-radiation) was used to characterize the crystalline phases present in biomass ashes and residues after the batch experiments. Each sample was grounded with a mortar and pestle and loaded into a plastic sample holder, flattened and compacted with a glass slide. The samples were step-scanned, integrated at $0.05^{\circ} 2 \theta$, over the range of $2^{\circ}-80^{\circ}$. XRD measurements were obtained using a thin film of powder sample at room temperature. EVA software was used, employing searchmatch access to the International Centre for Diffraction Data (ICDD) database for phase identification. Phases were identified on the basis of a match for at least three main peaks with phases in the ICDD database.

The morphology and microstructure of solid samples before and after the SAMD and AMD treatment were investigated by scanning electron microscopy (SEM) at different 
Table 2 Element composition in $\mathrm{mg} / \mathrm{L}$ and $\mathrm{pH}$ of raw AMDs

\begin{tabular}{lllllllll}
\hline Sample & $\mathrm{pH}$ & $\mathrm{Fe}$ & $\mathrm{Al}$ & $\mathrm{Zn}$ & $\mathrm{Cu}$ & $\mathrm{Cd}$ & $\mathrm{Ni}$ & $\mathrm{Co}$ \\
\hline Ursk AMD & 2.73 & 270 & 95 & 4.9 & 1.3 & $<0.01$ & 0.08 & 0.12 \\
Belovo AMD & 3.83 & 1.9 & 50 & 1000 & 1100 & 3.6 & 7.2 & 6.1 \\
GSDEP [49 ] & $6.0-9.0$ & 3.0 & - & 5.0 & 3.0 & 2.0 & 3.0 & - \\
\hline
\end{tabular}

magnifications on a JEOL JSM-6480LV high-performance, variable pressure analytical SEM with secondary electron imaging (SEI) and backscattered electron imaging (BEI) detectors. Individual solid particles and compacted samples were mounted rigidly on a specimen stub and coated with an ultrathin layer of carbon (graphite) or gold. Energy-dispersive X-ray spectroscopy (Oxford Instrument INCAx-sight EDS-system) was used for microanalysis of the solid phases viewed by SEM. SEM/EDS analyses were performed with a $15 \mathrm{keV}$ accelerating voltage. Certified standards were used for calibration. Reduction of element detection limits was achieved by using long counting times; typical element detection limits were about $0.1-0.05 \mathrm{wt} \%$. Element peaks were automatically identified in the EDS spectrum using AutoID, which also provided tools for manual validation of the elements detected.

\section{Results and Discussion}

\section{Synthetic Acid Mine Drainage Remediation with Biomass Ash (S-APCr)}

Figure 6 shows very little difference in the Fe, Mn and $\mathrm{Zn}$ concentrations left after the S-APCr addition at the $1 \mathrm{~h}$ and $24 \mathrm{~h}$ SAMD treatment experiments. Therefore, these elements were removed from the SAMD within the first hour. Due to this, only the results obtained for the $1 \mathrm{~h}$ experiment were discussed for the removal efficiency.

The $\mathrm{pH}$ value of the treated SAMD and the removal efficiencies for $\mathrm{Fe}, \mathrm{Zn}$, and $\mathrm{Mn}$ as a function of the SAMD/SAPCr ratios are shown in Fig. 7. Increase in $\mathrm{pH}$ and removal efficiencies for all investigated elements with increasing dosage of S-APCr were observed in all batch experiments. The lowest concentrations for $\mathrm{Fe}, \mathrm{Zn}$, and $\mathrm{Mn}$ in the treated SAMD $(\mathrm{Fe}=0.05 \mathrm{mg} / \mathrm{L}, \mathrm{Zn}=0.72 \mathrm{mg} / \mathrm{L}, \mathrm{Mn}=19 \mathrm{mg} / \mathrm{L})$ were indicated at the $\mathrm{L} / \mathrm{S}$ ratio of 100 . It was shown that the $\mathrm{S}-\mathrm{APCr}$ biomass ash efficiently treated the synthetic acid mine drainage, particularly at $\mathrm{L} / \mathrm{S}=100-250$ within $1 \mathrm{~h}$. At this $\mathrm{L} / \mathrm{S}$ ratio, the concentrations of potential pollutants such as $\mathrm{Fe}$ and $\mathrm{Zn}$ in the treated SAMD were below GSDEP concentrations (i.e. $\mathrm{Fe}=3.0 \mathrm{mg} / \mathrm{L} ; \mathrm{Zn}=5.0 \mathrm{mg} / \mathrm{L}$ ) and the $\mathrm{pH}$ value complied with the GSDEP $\mathrm{pH}$ value (i.e. $\mathrm{pH}$ 6.0-9.0). However, the removal efficiency for Mn was only up to 64\%, similar to results from Heviankova et al. [42] where Mn was not completely removed from AMD by wooden chip ash

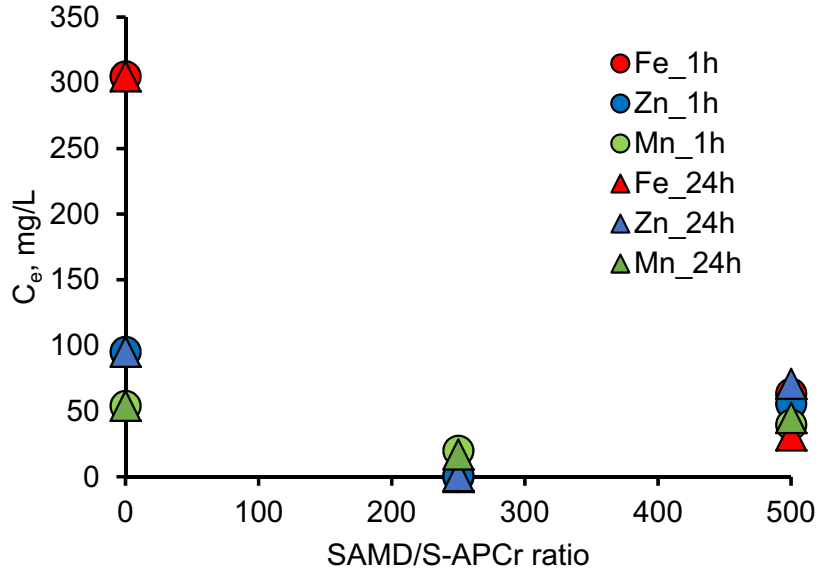

Fig. 6 Equilibrium concentration $\left(\mathrm{C}_{\mathrm{e}}\right)$ of $\mathrm{Fe}, \mathrm{Mn}$ and $\mathrm{Zn}$ as a function of SAMD/S-APCr ratio after $1 \mathrm{~h}$ and $24 \mathrm{~h}$ treatment

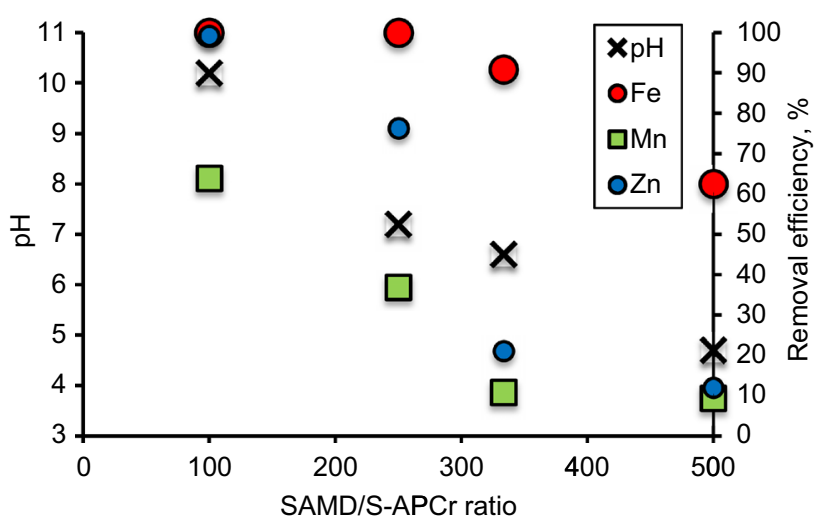

Fig. 7 The $\mathrm{pH}$ value of the treated SAMD and the removal efficiency (\%) for $\mathrm{Fe}, \mathrm{Zn}$, and $\mathrm{Mn}$ as a function of the SAMD/S-APCr ratio

(the removal efficiency of $\mathrm{Mn}=37-74 \%$ ) at the $\mathrm{L} / \mathrm{S}$ ratio of 345 with $\mathrm{pH} 8-9$. Mn expects to precipitate mainly as oxide and hydroxide during AMD treatment by biomass ashes. However, the $\mathrm{pH}$ value required to remove $\mathrm{Mn}$ should exceed $8.4[39,42,50]$.

The solid residues after the SAMD remediation with the S-APCr biomass ash were mainly amorphous materials (from XRD analysis). Those residues contained aggregates which consist of $\mathrm{Ca}, \mathrm{P}, \mathrm{Si}, \mathrm{K}, \mathrm{Cl}, \mathrm{Al}, \mathrm{S}, \mathrm{Fe}, \mathrm{Mn}$ and $\mathrm{Zn}$ (Fig. 8). According to Gitari et al. [39], AMDs are highly 

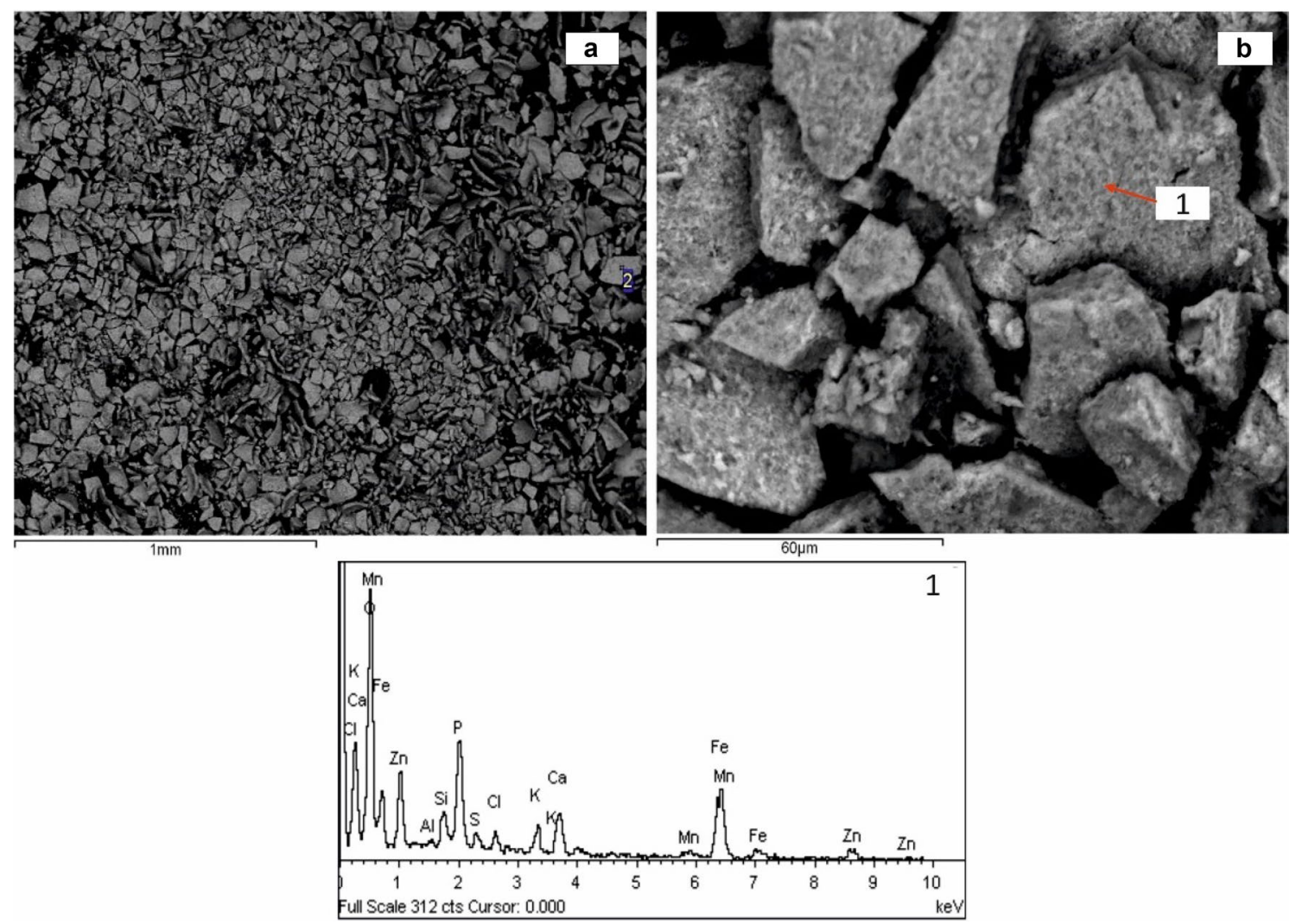

Fig. 8 Scanning electron microscopy images of the solid residues after the SAMD remediation with S-APCr: a and b SEM images of the solid residues; (1) elemental spectrum of point 1 from (b)

reactive solutions that can dissolve most primary minerals from alkaline solid wastes (e.g., coal fly ash) and secondary phases can be formed subsequently. Dissolution of primary phases (e.g., portlandite) of the S-APCr biomass ash lead to $\mathrm{pH}$ increase and triggers hydrolysis, adsorption, precipitation, co-precipitation and ion exchange processes [39, 51]. The removal of $\mathrm{Fe}, \mathrm{Al}$ and $\mathrm{Mn}$ could be mainly attributed to their hydroxide/oxyhydroxide precipitation/co-precipitation that depends on $\mathrm{pH}$ (the $\mathrm{pH}$ of minimum solubility of the hydroxides/oxyhydroxides of $\mathrm{Fe}^{3+}, \mathrm{Fe}^{2+}, \mathrm{Al}^{3+}, \mathrm{Mn}^{2+}$ are 3.0, 6.0-8.0, 4.0-4.5, 8.4-9.0, respectively; [39]).

\section{Raw Acid Mine Drainage Remediation with the Biomass Ashes (S-APCr, MBM-BA, PL2-BA and PL3-BA)}

The $\mathrm{pH}$ value of the treated AMD and removal efficiencies $(\%)$ at the different AMD/BA ratios are shown in Figs. 9 and 10. Increases in $\mathrm{pH}$ were observed in all batch experiments.

For the 500 Ursk AMD/BA ratio, the $\mathrm{pH}$ value changed slightly (Fig. 9). Decreasing the Ursk AMD/BA ratio up to 200 showed that the $\mathrm{pH}$ reached slightly acidic values, particularly, after the addition of S-APCr and PL2-BA. The near neutral, slightly acidic or alkaline $\mathrm{pH}$ values of treated
AMDs were identified at the 50-200 Ursk AMD/BA ratio (Fig. 9). A decrease of the Ursk AMD/BA ratio to 10 led to the $\mathrm{pH}$ value of the Ursk AMD increasing up to 9.78-11.99. The treated Belovo AMD became slightly acidic (4.58-5.70) at the 50-500 L/S ratio for the MBM-BA, PL2-BA, and PL3$\mathrm{BA}$, and at the 100-500 L/S ratio for the S-APCr (Fig. 10). The addition of the S-APCr to the Belovo AMD at the 50 $\mathrm{L} / \mathrm{S}$ ratio led to increase $\mathrm{pH}$ up to neutral value. Similar behaviour was observed for the poultry litter biomass ashes added to the Belovo AMD at the $10 \mathrm{~L} / \mathrm{S}$ ratio. A decrease of the Belovo AMD/S-APCr and Belovo AMD/MBM-BA ratios to ten increased the $\mathrm{pH}$ of the Belovo AMD up to 10.47 and 11.44 , respectively. The ability of biomass ashes of CPK type and PK type with low acid (LA) tendency to adjust $\mathrm{pH}$ agrees with results obtained by Heviankova et al. [42] for the biomass ashes from the wooden chip combustion (CS-MA type) and by Nasir et al. [43] for coal fly ash (SC-MA type). However, rice husk ash (S-HA type) was not very effective for AMD neutralisation [43].

The removal efficiency of Fe from the Ursk AMD was very high $(95-100 \%)$ at the AMD/BA ratio up to 200 for MBM-BA, PL3-BA and S-APCr, and up to 500 for PL2-BA (Fig. 9). Al was removed by biomass ashes (i.e. PL2-BA, PL3-BA, and S-APCr) from the Ursk AMD at the L/S ratio 

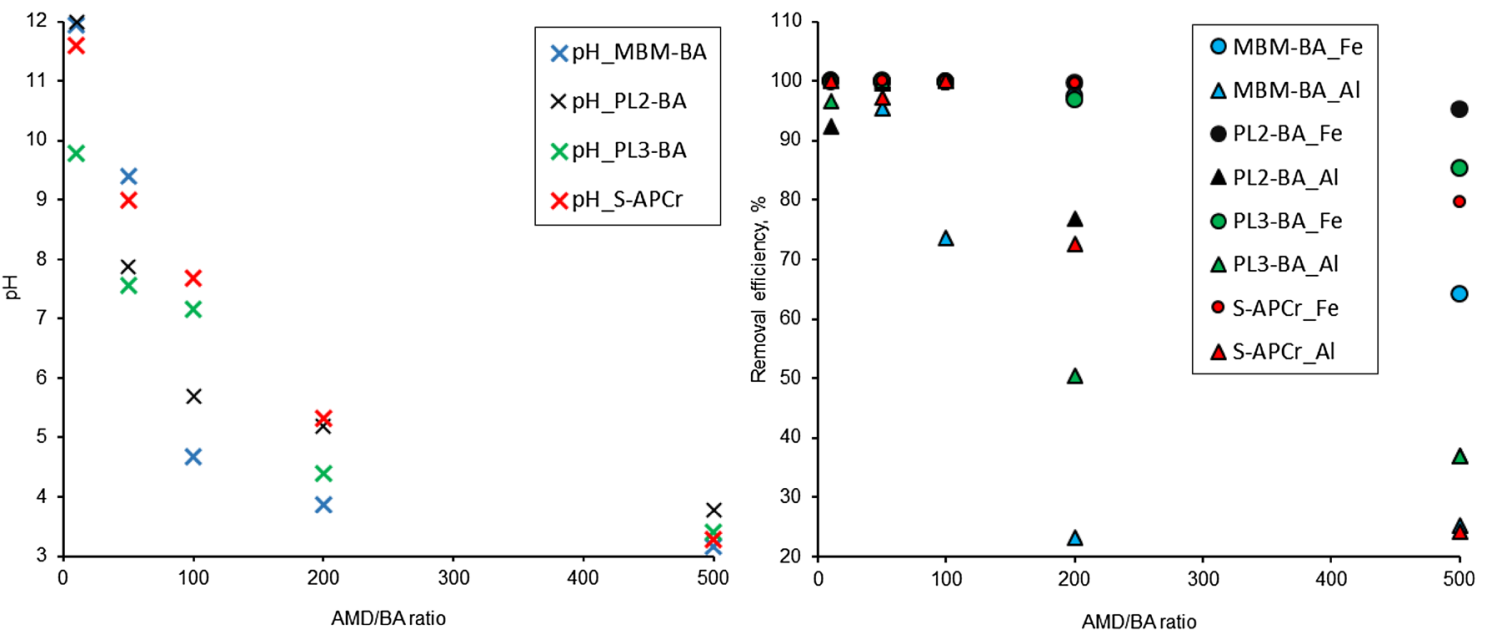

Fig. 9 The $\mathrm{pH}$ value of the treated Ursk AMD and the removal efficiency (\%) for $\mathrm{Fe}$ and $\mathrm{Al}$ as a function of the AMD/BA ratio

up to 100. However, MBM-BA was less efficient for $\mathrm{Al}$ and could remove it at the $\mathrm{L} / \mathrm{S}$ ratio up to 50 . It was shown that the biomass ash from straw and poultry litter combustion at $\mathrm{L} / \mathrm{S}=100$ could effectively adjust $\mathrm{pH}$ in the Ursk AMD with removal of potential pollutants: (1) S-APCr- $\mathrm{pH} 7.68$, $\mathrm{Fe}=0.14 \mathrm{mg} / \mathrm{L}, \mathrm{Al}, \mathrm{Zn}, \mathrm{Cu}, \mathrm{Ni}$, and $\mathrm{Co}-$ below the detection limit); (2) PL2-BA—pH 5.69, Fe $=0.27 \mathrm{mg} / \mathrm{L}, \mathrm{Zn}=0.5 \mathrm{mg} / \mathrm{L}$, $\mathrm{Cu}=0.47 \mathrm{mg} / \mathrm{L}, \mathrm{Al}, \mathrm{Ni}$, and $\mathrm{Co}-$ below the detection limit); (3) $\mathrm{PL} 3-\mathrm{BA}-\mathrm{pH} 7.17, \mathrm{Fe}=0.56 \mathrm{mg} / \mathrm{L}, \mathrm{Zn}=1.7 \mathrm{mg} / \mathrm{L}$, $\mathrm{Cu}=0.62 \mathrm{mg} / \mathrm{L}, \mathrm{Al}, \mathrm{Ni}$, and $\mathrm{Co}$ - below the detection limit).

The removal efficiency of pollutants increased with decreasing the Belovo AMD/BA ratio from 500 to 10 (Fig. 10). All investigated biomass ashes could effectively treat highly polluted Belovo AMD at $\mathrm{L} / \mathrm{S}=10$ : (1) MBM-BA-pH 11.44, $\mathrm{Zn}=0.3 \mathrm{mg} / \mathrm{L}, \mathrm{Cu}=16 \mathrm{mg} / \mathrm{L}$, $\mathrm{Fe}, \mathrm{Al}, \mathrm{Cd}, \mathrm{Ni}$, and $\mathrm{Co}-$ below the detection limit); (2) $\mathrm{PL} 2-\mathrm{BA}-\mathrm{pH}=6.74, \mathrm{Fe}=0.02 \mathrm{mg} / \mathrm{L}, \mathrm{Zn}=0.2 \mathrm{mg} / \mathrm{L}$,
$\mathrm{Cu}=1.2 \mathrm{mg} / \mathrm{L}, \mathrm{Al}, \mathrm{Cd}, \mathrm{Ni}$, and $\mathrm{Co}-$ below the detection limit); (3) PL3-BA-pH 6.18, $\mathrm{Zn}=46 \mathrm{mg} / \mathrm{L}, \mathrm{Cu}=48 \mathrm{mg} / \mathrm{L}$, $\mathrm{Cd}=0.27 \mathrm{mg} / \mathrm{L}, \mathrm{Ni}=1.8 \mathrm{mg} / \mathrm{L}, \mathrm{Co}=1.7 \mathrm{mg} / \mathrm{L}, \mathrm{Al}$ and $\mathrm{Fe}-$ below the detection limit); (4) S-APCr- $\mathrm{pH} 10.47$, $\mathrm{Zn}=1.7 \mathrm{mg} / \mathrm{L}, \mathrm{Cu}=0.69 \mathrm{mg} / \mathrm{L}, \mathrm{Al}=0.14 \mathrm{mg} / \mathrm{L}, \mathrm{Fe}, \mathrm{Cd}, \mathrm{Ni}$, and $\mathrm{Co}-$ below the detection limit). The S-APCr biomass ash could remove $99.5 \%$ of $\mathrm{Cu}$ and $48.1 \%$ of $\mathrm{Zn}$ from the Belovo AMD at $\mathrm{L} / \mathrm{S}=30$ (Fig. 10).

Prasad and Mortimer [33] treated two different AMDs from the UK using coal fly ashes from India at the 25-200 $\mathrm{L} / \mathrm{S}$ ratios and showed that coal fly ashes were effective for removal of $\mathrm{Pb}$, but increased dosing caused release of $\mathrm{Ba}$, $\mathrm{Cr}, \mathrm{Sr}, \mathrm{Zn}, \mathrm{Ni}$, and $\mathrm{Fe}$ into AMDs because coal fly ashes generally contain elevated concentrations of potential pollutants. Also, coal fly ash mainly consists of $\mathrm{Si}$ and $\mathrm{Al}$ and contains crystalline phases such as quartz and mullite, and is different in phase and elemental composition compared with biomass
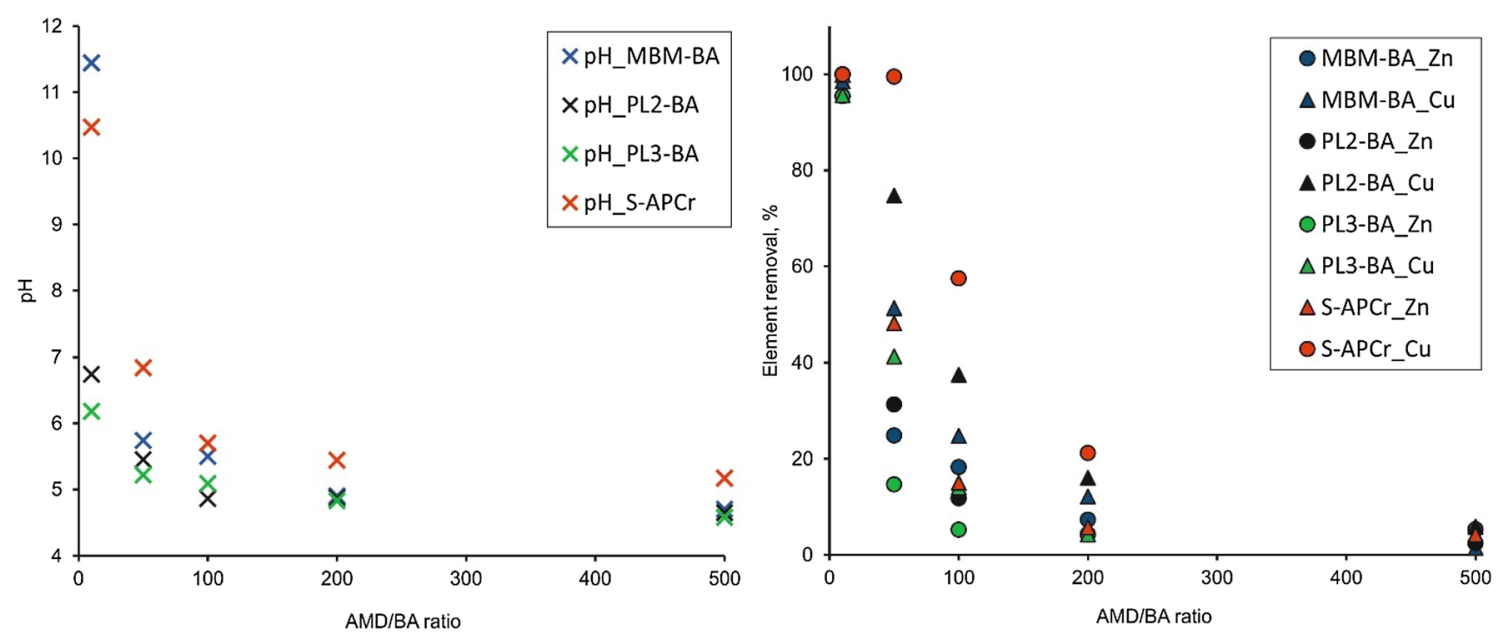

Fig. 10 The $\mathrm{pH}$ value of the treated Belovo AMD and the removal efficiency (\%) for $\mathrm{Zn}$ and $\mathrm{Cu}$ as a function of the AMD/BA ratio 

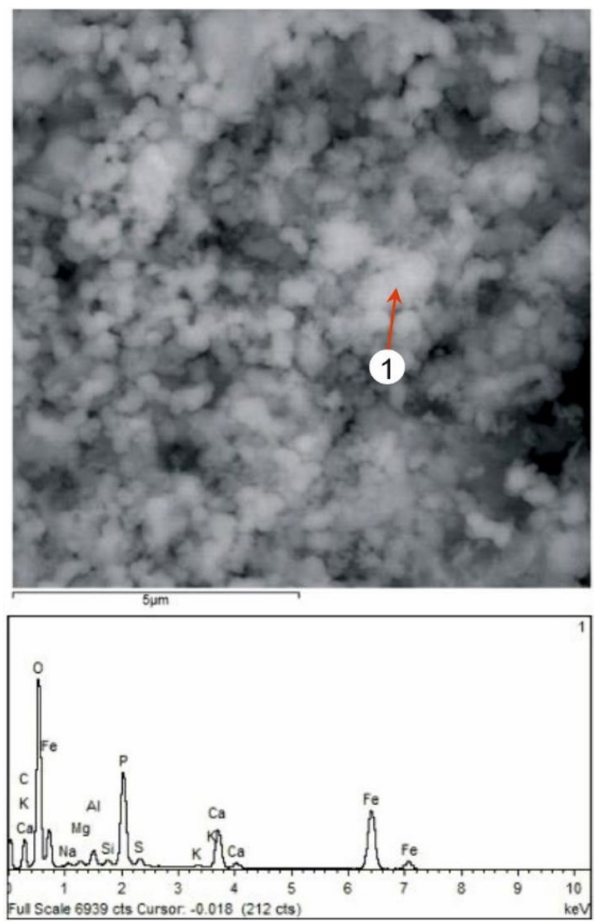

Fig. 11 Scanning electron microscopy image and EDS spectrum of the solid residues after the Ursk AMD remediation with biomass ashes ashes as discussed in introduction. Therefore, the mechanism of element removal using biomass and coal ash might be different.

The solid residues after the Ursk AMD and Belovo AMD remediation with the biomass ashes were mainly amorphous materials that represent aggregates and fine phases (Figs. 11 and 12). The residue from the Ursk AMD treatment mainly consists of $\mathrm{Fe}, \mathrm{Ca}, \mathrm{P}$, and $\mathrm{O}$, probably $\mathrm{Ca}, \mathrm{Fe}$ phosphate (Fig. 11). Also, Fe oxyhydroxides were identified in the residues. Apatite and other phosphates identified in the bottom biomass ashes (MBM-BA, PL2-BA, and PL3-BA) are partly dissolved by highly acidic AMD and then other phosphates are precipitated/co-precipitated in the treated AMD. This was not observed in previous work based on wood and rice husk ashes [42-44] because those biomass ashes do not contain high content of P-bearing phases and belong to different types according to Vassilev's chemical classification for biomass ashes [27].

The fine phases of the solid residue after the Belovo AMD treatment consist of $\mathrm{Ca}, \mathrm{Cu}, \mathrm{Zn}, \mathrm{O}$ (hydroxides); $\mathrm{Ca}, \mathrm{Cu}, \mathrm{Zn}$, C, O (carbonates); Ca, Cu, Zn, S, O (sulphates) (Fig. 12). Some fine phases, spherical and irregular-shaped particles contain $\mathrm{Ca}, \mathrm{P}$, and $\mathrm{O}$ (probably $\mathrm{Ca}$ phosphate) with impurities of $\mathrm{Cu}$ and $\mathrm{Zn}$ (Fig. 12). Again, portlandite, calcite,

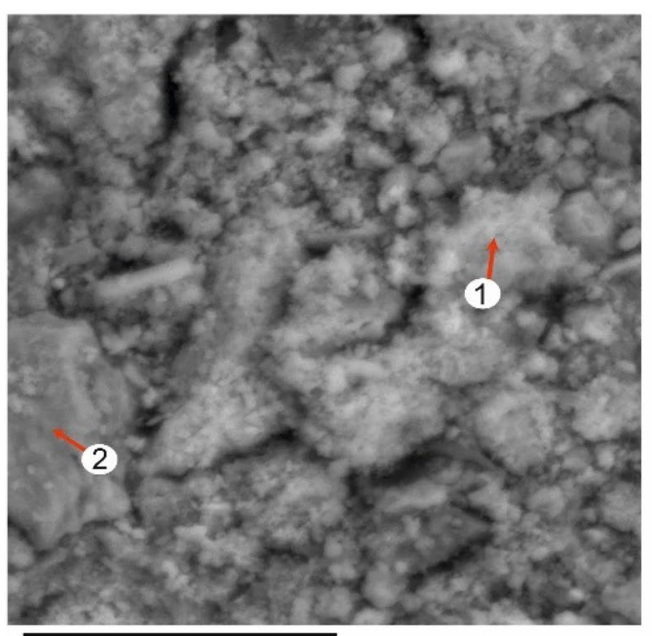

$50 \mu \mathrm{m}$
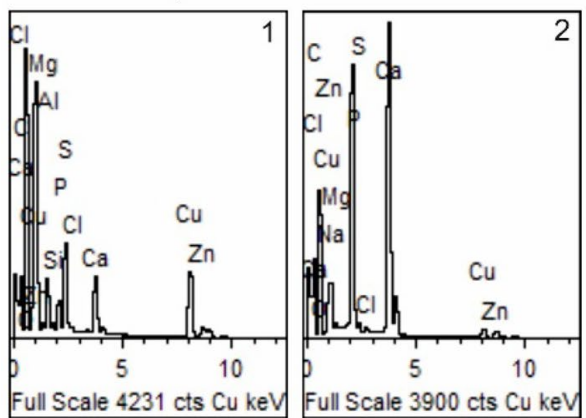

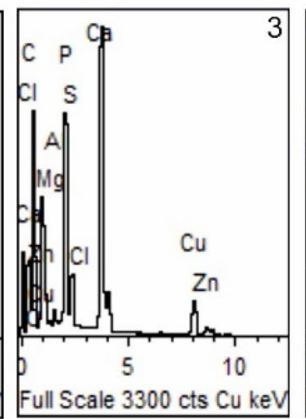

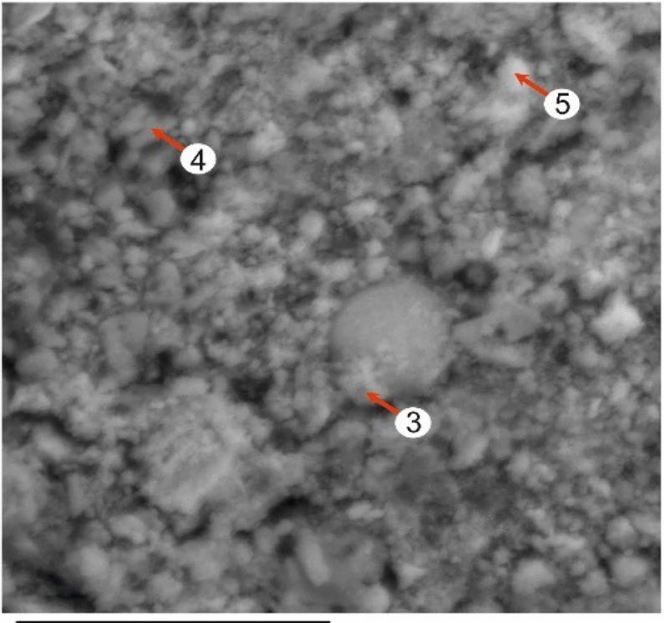

$40 \mu \mathrm{m}$
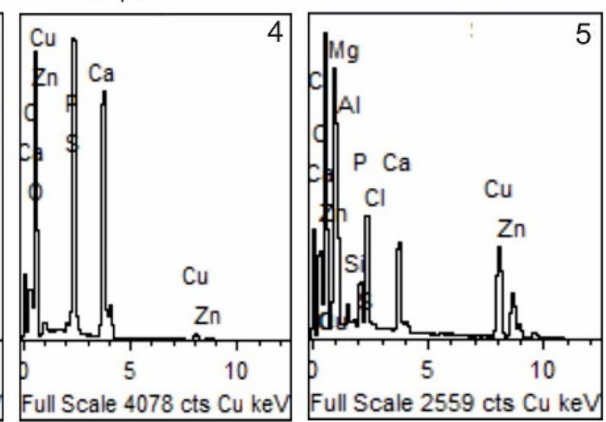

Fig. 12 Scanning electron microscopy images and EDS spectra of the solid residues after the Belovo AMD remediation with biomass ashes 
apatite, and other phosphate present in the biomass ashes are completely or/and partly dissolved in the Belovo AMD and potential pollutants are immobilized in secondary phases formed in the solution. Adsorption or cation exchange might be also accrued in this complex system.

\section{Conclusions}

The biomass ashes from the incineration of straw (PK-LA type), meat and bone meal (CPK-LA type), and poultry litter (CPK-LA type) from the UK biomass power plants are alkaline materials and contain high concentrations of $\mathrm{Ca}$ and $\mathrm{P}$ presented in the bulk crystalline phases including portlandite, calcite, apatite and other phosphates.

The batch experiments showed that the biomass ash from the straw combustion can effectively treat the synthetic AMD at the L/S ratio of 100-250 with adjusting $\mathrm{pH}$ of SAMD and removing potential pollutants (e.g., removing efficiency for $\mathrm{Fe}$ and $\mathrm{Zn}$ up to $100 \%$ and for $\mathrm{Mn}$ up to $64 \%$ ) in $1 \mathrm{~h}$.

The biomass ashes from straw and poultry litter combustion could effectively remove pollutants from the Ursk AMD at L/S 100 and adjust $\mathrm{pH}$ up to 5.7-7.8. The S-APCr biomass ashes were effective for the Belovo AMD treatment at $\mathrm{L} / \mathrm{S}$ $10-50$ with $\mathrm{pH}$ adjustment.

Potential pollutants precipitated as carbonate/hydroxide/ sulphate, co-precipitated with other phases (e.g., Fe oxyhydroxides, $\mathrm{Ca}$ phosphates) and appeared as new phases such as $\mathrm{Ca}, \mathrm{Cu}, \mathrm{Zn}$ phosphates and $\mathrm{Ca}, \mathrm{Fe}$ phosphates, that expect to have low solubility product. Also, metals might be adsorbed on the surface of biomass ash particles and new formed phases.

All investigated biomass ashes from PK-LA and CPK-LA type showed potential for AMD treatment. However, biomass ashes from straw and poultry litter can be considered as the most effective, environmentally friendly and low-cost potential material for AMD treatment both for potential pollutants immobilisation and $\mathrm{pH}$ adjustment.

Vassilev's chemical classification for biomass ashes [27] with the additions from [28] is very useful to make appropriate selection of untested ashes for effective AMD treatment and predict their performance based on knowledge of ash compositions. Priority should be given to $\mathrm{C}$ type and/or intermedium types such as CS, CPK, and PK types with low and/or medium acid tendency.

Recommendations for further investigation include: comprehensive investigation of element speciation in the residues after AMD treatment by biomass ashes in order to understand this complex system and investigate mechanisms for the immobilization of metals; design and run trial field experiments with a detailed economical evaluation, for example, design a permeable reactive barrier where biomass ash can be used as the reaction medium for AMD treatment or/and using biomass ashes instead of limestone in tailings ponds or wetlands.

Acknowledgements The authors gratefully acknowledge the valuable assistance of the following people: Prof. Julia Stegemann from CEGE UCL, Rob Carroll at the UK Quality Ash Association, and Mark Westwood from Fibrophos, for assistance in obtaining biomass ash samples; Dr. Denisa Jianu, Prof. Gyuri Ilinca and Dr. Barbara Soare from the Faculty of Geology (University of Bucharest, Romania), for providing us with supporting information on the chosen polluted area in Romania, Mr. Dragos Mitrică for assisting with the water sample collection and Ecoind for providing us with free analyses for the wastewater samples from Almaşu Mare (Romania); Judith Zhou for supporting in the UCL CEGE laboratory; Mr. Martin Vickers in UCL Chemistry for supporting with XRD analysis. This work was partially supported by the National Research Foundation of Korea (NRF) and the Korean Government (MOE) (Grant No. 2017R1D1A1B03032181).

Open Access This article is distributed under the terms of the Creative Commons Attribution 4.0 International License (http://creativeco mmons.org/licenses/by/4.0/), which permits unrestricted use, distribution, and reproduction in any medium, provided you give appropriate credit to the original author(s) and the source, provide a link to the Creative Commons license, and indicate if changes were made.

\section{References}

1. GARD/INAP: The global acid rock drainage guide/the international network for acid prevention. https://www.gardguide.com/ index.php?title=Main_Page.

2. Nordstrom, D.K., Alpers, C.N.: Geochemistry of Acid Mine Waters, pp. 117-123. Society of Economic Geologists, Littleton (1999)

3. Younger, P.L., Banwart, S.A., Hedin, R.S.: Mine WaterHydrology, Pollution, Remediation. Kluwer, Dordrecht (2002)

4. Jambor, J.L., Blowes, D.W., Ritchie, A.I.M.: Environmental Aspects of Mine Wastes. Mineral Association of Canada Short Course, Quebec (2003)

5. Lottermoser, B.G.: Mine Wastes: Characterization, Treatment and Environmental Impacts, 2nd edn. Springer, Berlin (2007)

6. Wolkersdorfer, C.: Water Management at Abandoned Flooded Underground Mines-Fundamentals, Tracer Tests, Modelling, Water Treatment. Springer, Heidelberg (2008)

7. Nordstrom, D.K.: Mine waters: acidic to circumneutral. Elements 7, 393-398 (2011)

8. Hudson-Edwards, K.A., Jamieson, H.E., Lottermoser, B.G.: Mine wastes: past, present, future. Elements 7, 375-380 (2011)

9. Bogush, A.A., Voronin, V.G., Tikhova, V.D., Anoshin, G.N.: Acid rock drainage remediation and element removal using a peat-humic agent with subsequent thermal treatment of the metalorganic residue. Miner. Water Environ. 35(4), 536-546 (2016)

10. Nordstrom, D.K., Alpers, C.N., Ptacek, C.J., Blowes, D.W.: Negative $\mathrm{pH}$ and extremely acidic mine waters from iron mountain. California. Environ. Sci. Technol. 34(2), 254-258 (2000)

11. Gazea, B., Adam, K., Kontopoulos, A.: A review of passive systems for the treatment of acid mine drainage. Miner. Eng. 9(1), 23-42 (1996)

12. Akcil, A., Koldas, S.: Acid mine drainage (AMD): causes, treatment and case studies. J. Clean. Prod. 14(12-13), 1139-1145 (2006) 
13. WEF-Water Environment Federation: Industrial Wastewater Management, Treatment and Disposal. WEF Manual of Practice No. FD-3. 3rd ed. Alexandria: WEF Press (2008).

14. Trumm, D.: Selection of active and passive treatment systems for AMD_flow charts for New Zealand conditions. N. Z. J. Geol. Geophys. 53(2-3), 195-210 (2010)

15. Skousen, J., Zipper, C.E., Rose, A., Ziemkiewicz, P.F., Nairn, R., McDonald, L.M., Kleinmann, R.L.: Review of passive systems for acid mine drainage treatment. Mine Water Environ. 36, 133-153 (2017)

16. Gabr, M.A., Bowders, J.J.: Controlled low-strength material using fly ash and AMD sludge. J. Hazard. Mater. 76, 251-263 (2000)

17. Lee, T., Park, J., Lee, J.: Waste green sands as reactive media for the removal of zinc from water. Chemosphere 56, 571-581 (2004)

18. Somerset, V., Petrik, L., Iwuoha, E.: Alkaline hydrothermal conversion of fly ash filtrates into zeolite 2: utilization in wastewater treatment. J. Environ. Sci. Heal. 40, 1627-1636 (2005)

19. Somerset, V., Petrik, L., Iwuoha, E.: Alkaline hydrothermal conversion of fly ash filtrates into zeolite 3: the removal of mercury and lead ion from wastewaters. J. Environ. Manage. 87(1), 125131 (2008)

20. Chockalingam, E., Subramanian, S.: Studies on removal of metal ions and sulphate reduction using rice husk and Desulfotomaculum nigrificans with reference to remediation of acid mine drainage. Chemosphere 62, 699-708 (2006)

21. Herrera, P., Uchiyam, H., Igarashi, T., Asakura, K., Ochi, Y., Iyatomi, N., Nagae, S.: Treatment of acid mine drainage through a ferrite formation process in central Hokkaido, Japan: evaluation of dissolved silica and aluminium interference in ferrite formation. Miner. Eng. 20, 1255-1260 (2007)

22. Cravotta, C.A., Ward, S.J.: Downflow limestone beds for treatment of net-acidic, oxic,iron-laden drainage from a flooded anthracite mine, Pennsylvania, USA: 1. Field evaluation. Miner. Water Environ. 27, 67-85 (2008)

23. Kumar Vadapalli, V.R., Klink, M.J., Etchebers, O., Petrik, L.F., Gitari, W., White, R.A., Key, D., Iwuoha. E.: Neutralization of acid mine drainage using fly ash, and strength development of the resulting solid residues. S. Afr. J. Sci., 104, 317-324 (2008).

24. Rios, C.A., Williams, C.D., Roberts, C.L.: Removal of heavy metals from acid mine drainage (AMD) using coal fly ash, natural clinker and synthetic zeolites. J. Hazard. Mater. 156, 23-35 (2008)

25. Gitari, W.M., Petrik, L.F., Etchebers, O., Key, D.L., Iwuoha, E., Okujeni, C.: Passive neutralisation of acid mine drainage by fly ash and its derivatives: a column leaching study. Fuel 87, 16371650 (2008)

26. Vassilev, S.V., Baxter, D., Andersen, L.K., Vassileva, C.G.: An overview of the chemical composition of biomass. Fuel 89, 913$933(2010)$

27. Vassilev, S.V., Baxter, D., Andersen, L.K., Vassileva, C.G.: An overview of thecomposition and application of biomass ash. Part 1. Phase-mineral and chemicalcomposition and classification. Fuel 105, 40-76 (2013)

28. Bogush, A.A., Stegemann, J.A., Williams, R., Wood, I.G.: Element speciation in UK biomass power plant residues based on composition, mineralogy, microstructure andlLeaching. Fuel 211, 712-725 (2018)

29. Demirbas, A.: Potential applications of renewable energy sources, biomass combustion problems in boiler power systems and combustion related environmental issues. Prog. Energy Combust. Sci. 31, 171-192 (2005)

30. Vassilev, V.S., Baxter, D., Andersen, L.K., Vassileva, C.G.: An overview of thecomposition and application of biomass ash. Part 2. Potential utilisation, technological andecological advantages and challenges. Fuel 105, 19-39 (2013)

31. Barnes, D.I., Sear, L.K.A.: Ash utilisation from coal-based power plants. Proceedings of the Conference "AshTech 2006-Ash
Technology", UKQAA, 15-17 May 2006, Birmingham, UK (2006).

32. Vassilev, S.V., Vassileva, C.G., Vassilev, V.S.: Advantages and disadvantages of composition and properties of biomass in comparison with coal: an overview. Fuel 158, 330-350 (2015)

33. Prasad, B., Mortimer, R.J.G.: Treatment of acid mine drainage using fly ash zeolite. Water Air Soil Pollut. 218(1-4), 667-679 (2011)

34. Seoane, S., Leiros, M.C.: Acidification-neutralization processes in a lignite mine spoil amended with fly ash or limestone. J. Environ. Qual. 30(4), 1420-1431 (2001)

35. Anthimos, X., Mylona, E., Paspaliaris, I.: Potential use of lignite fly ash for the control of acid generation from sulphidic wastes. Waste Manage. 22, 631-641 (2002)

36. Potgieter-Vermaak, S.S., Potgieter, J.H., Monama, P., Van Grieken, R.: Comparison of limestone, dolomite and fly ash as pre-treatment agent for acid mine drainage. Miner. Eng. 19, 454 $462(2006)$

37. Xu, J., Wan, H.: Study on the Treatment of Acid Mine Wastewater by Coal Fly Ash. In: Proceedings of the International Conference on Material and Environmental Engineering (ICMAEE), Atlantis (2014).

38. Quresh, A., Jia, Y., Maurice, C., Ohlander, B.: Potential of fly ash for neutralisation of acid mine drainage. Environ. Sci. Pollut. Res. 23(17), 17083-17094 (2016)

39. Gitari, W.M., Petrik, L.F., Akinyemi, S.A.: Treatment of acid mine drainage with coal fly ash: exploring the solution chemistry and product water quality. In Akinyemi SA (ed) Coal Fly Ash Beneficiation. InTech, Rijeka (2018).

40. Perez-Lopez, R., Nieto, J.M., Ruiz de Almodovar, G.: Utilisation of fly ash to improve the quality of the acid mine drainage generated by oxidation of a sulphide-rich mining waste: column experiments. Chemosphere, 67, 1637-1646 (2007).

41. Kumar Vadapalli, V.R., Klink, M.J., Etchebers, O., Petrik, L.F., Gitari, W., White, R.A., Key, D., Iwuoha, E.: Neutralization of acid mine drainage using fly ash, and strength development of the resulting solid residues. S Afr J Sci 104, 317-322 (2008)

42. Heviankova, S., Spakovska, B., Klimko, T., Kyncl, M., Bilska, Z., Kucerova, L.: Acid mine drainage treatment by ash from wooden chip combustion: study of mine water composition in dependence on the ash dose and duration of mutual interaction. Carpathian J. Earth Environ. Sci. 9(2), 159-170 (2014)

43. Nasir, S., Ibrahim, E., Arief, A.T.: Design and experimental testing of small-scale acid mine drainage treatment plant. J. Mater. Environ. Sci. 7(8), 2912-2918 (2016)

44. Mohammed, N.H., Atta, M., Yaacub, W.Z.W.: Remediation of heavy metals by using industrial waste by products in acid mine drainage. American J. Eng. App. Sci. 10(4), 1001-1012 (2017)

45. Borcos, M., Udubasa, G.: Chronology and characterisation of mining development in Romania. Romanian J. Earth Sci. 86(1), 17-26 (2012)

46. Toth, A., Quiquerez, A.: Past and present mining in the apuseni mountains. Romania Field Trip SEG Student Chapters (2006).

47. Sima, M., Dold, B., Frei, L., Senila, M., Balteanu, D., Zobrist, J.: Sulfide oxidation and acid mine drainage formation within two active tailings impoundments in the Golden Quadrangle of the Apuseni Mountains. Romania. J. Hazard. Mater. 189, 624-639 (2011)

48. European Commision: Environment: Commission takes Romania to Court over toxic tailing pond (2014). https://europa.eu/rapid/ press-release_IP-14-1149_en.htm

49. GSDEP: General Standards for Discharge of Environmental Pollutants (Part A: effluents). Environmental standards, GSR 801 (E), dated Dec. 311986 (1993). 
50. Aziz, H.A., Smith, P.G.: The influence of $\mathrm{pH}$ and coarse media on manganese precipitation from water. War. Res. 26(6), 853-855 (1992)

51. Erol, M., Kucukbayrak, S., Ersoy-Mericboyu, A., Ulubas, T.: Removal of $\mathrm{Cu}^{2+}$ and $\mathrm{Pb}^{2+}$ in aqueous solutions by fly ash. Energy Conserv. Manag. 46, 1319-1331 (2005)
Publisher's Note Springer Nature remains neutral with regard to jurisdictional claims in published maps and institutional affiliations.

\section{Affiliations}

\section{Anna A. Bogush ${ }^{1,2,3} \cdot$ Cosmina Dabu $^{4} \cdot$ Vera D. Tikhova $^{5} \cdot$ Jong Kyu Kim$^{6} \cdot$ Luiza C. Campos $^{7}$ (D)}

\section{Luiza C. Campos}

1.campos@ucl.ac.uk

1 Department of Earth Sciences, University College London (UCL), Gower Street, London WC1E 6BT, UK

2 Institute of Geology and Mineralogy SB RAS, Ac. Koptyuga ave. 3, Novosibirsk 630090, Russia

3 Centre for Agroecology, Water and Resilience, Coventry University, Coventry CV8 3LG, UK

4 Department of Chemistry, UCL, Gordon Street, London WC1H 0AJ, UK
5 Institute of Organic Chemistry SB RAS, Ac. Lavrentieva ave. 9, 630090 Novosibirsk, Russia

6 Department of Civil Engineering, Kyungnam University, Changwon, Republic of Korea

7 Department of Civil, Environmental \& Geomatic Engineering (CEGE), University College London (UCL), Chadwick Building, Gower Street, London WC1E 6BT, UK 